\title{
Mergers and Acquisitions: Does it really Enhance Managerial Commitment? Evidence from Commercial Banks in South East Nigeria
}

\author{
J.U.J Onwumere ${ }^{1}$, Onodugo V.A ${ }^{2}$, O.C Ugbam ${ }^{3}$, Imo G. Ibe ${ }^{4}$, Monanu Oge \\ ${ }^{1}$ Department of Banking and Finance, University of Nigeria, Enugu Campus, Enugu, Nigeria \\ Email: josaphatonwumere@yahoo.com \\ ${ }^{2}$ Department of Management University of Nigeria, Enugu Campus, Enugu, Nigeria \\ Email: vincentonodugo@yahoo.com \\ ${ }^{3}$ Department of Management University of Nigeria, Enugu Campus, Enugu, Nigeria \\ Email: ogechim042@yahoo.com \\ ${ }^{4}$ Department of Banking and Finance, Renaissance University, Ugbawka, Enugu, Nigeria \\ Email: imoibe4real@yahoo.co.in \\ ${ }^{5}$ Department of Management, Godfrey Okoye University, Enugu Nigeria
}

\begin{abstract}
Corporate mergers and acquisition has become a highly popular strategy in recent years. Thus, much attention has been focused on its outcomes. It has served as a substitute for innovation, a greater means of diversification. The banking sector is often referred to as an engine growth of the economy. The intermediation role which the sector plays in national development cannot be overemphasized. Thus, given the recent consolidation exercise in the Nigerian banking sector, we explored the impact of mergers and acquisition on managerial commitment in this paper. We adopted the descriptive survey method and primary data were obtained using oral interview and questionnaire. The population of this study comprised all consolidated banks in Nigeria and the total sample size for this study was 384 respondents from commercial banks in South East Nigeria. The Chi-square $\left(X^{2}\right)$ non-parametric statistic was used to test the hypotheses. The results revealed that mergers and acquisitions have significant positive effect on managerial role and commitment of managers of commercial banks in Nigeria's South East Region. We, therefore, recommend that incentive measures such as improved pay and good working environment should be promoted in commercial banks during mergers and acquisitions as these will further enhance managerial commitment.
\end{abstract}

Keywords: Mergers and Acquisitions; Managerial Commitment; Commercial Banks; South East Nigeria

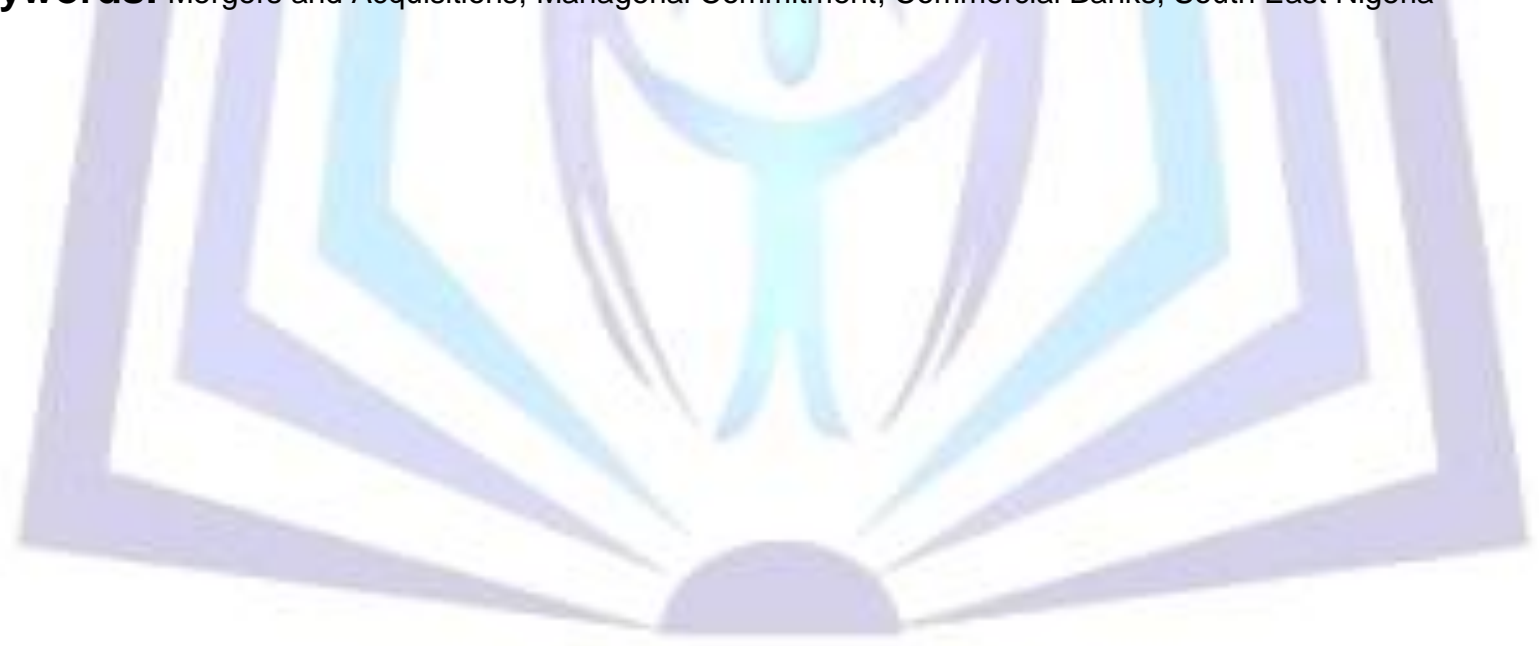

\section{Council for Innovative Research}

Peer Review Research Publishing System

Journal: International Journal of Management \& Information Technology

Vol. 6, No. 2

editor@cirworld.com

www.cirworld.com, member.cirworld.com 


\section{INTRODUCTION}

Over the past decade, a lot of research has been devoted to whether managerial commitment is enhanced through mergers and acquisitions. Literature examined suggests that there is a substantial potential for improvements in management of financial institutions from mergers and acquisitions. Most recent analyses find unexploited economies of scale even for fairly large entities in the US (Berger and Mester, 1997; Berger and Humphrey, 1997) and in Europe (Allen and Rai, 1996; Molyneux et al, 1996; Vander, 2001).

Literature again suggests that the prospects for scale efficiency gains appear to be greater in the 1990s than in the 1980s with findings usually ascribed to technological progress and regulatory changes (Berger, et. al., 1999). Yet, a lot of studies conclude that the potential gains are seldom realized. Studies on mergers find little or no improvements in management efficiency on average (DeYoung, 1997; Peristiani, 1996; Berger, 1998). It appears therefore that, the potential gains from consolidating operations may have been offset by managerial inefficiencies or problems in integrating systems.

Case study evidence suggests that the efficiency effects of mergers and acquisition may depend on the motivation behind the mergers process (Rhoades, 1998). Haynes and Thompson (1999) had explored the productivity effects of acquisitions for a panel of 93 UK building societies over the period 1981-1993 with results indicating significant and substantial productivity gains following acquisition. Through, these gains were not found to have resulted from economies of scale, there were nevertheless found to be consistent with a merger processes in which assets are transferred to the control of more productive managements. These results contrasted with much of existing merger literature.

Mergers and acquisitions recently have become a highly popular restructuring strategy all around the world. Thus, much attention has been focused on its outcomes. Specifically, the extent mergers and acquisitions serves as a substitute for innovation, energy and attention required during negotiations, increased use of leverage, increased size, and the greater diversification may have on managers' risk orientations. Because of these effects, managers may reduce their commitment to innovation (Hitt, Hoskisson and Ireland, 1990).

In Nigeria, mergers and acquisitions became more popular during the 2005 consolidation exercise of banks. The primary objective according to the then Governor of Central Bank of Nigeria Soludo, for the government induced mergers and acquisition was to guarantee an efficient and sound financial system and as such the reform was designed to enable the banking system develop the required resilience to support the economic development of the nation by efficiently performing its functions as the fulcrum of financial intermediation through strong management commitment (Lemo, 2005). Thus, the reforms were designed at ensuring the safety of depositors' money as well positioning banks to play active developmental roles in the Nigerian economy.

The banking sector is often referred to as an engine of growth of the economy. The intermediation role which the sector plays in national development cannot be overemphasized. Managerial commitment is thus vital for the success of this important sector of the Nigerian economy. It is against the importance of the banking sector that we explored the impact of mergers and acquisitions on managerial commitment in the Nigerian banking industry. Our paper is subsequently divided into five sections. Section one is the introduction. In section two, we reviewed related literature. Section three contains our methodology, while section four discusses the results of our findings. Lastly, in section five, we provided recommendations based on evidence, inclusive of our conclusion.

\section{REVIEW OF RELATED LITERATURE}

Managers may be able to pursue their own objectives in mergers and acquisitions (M\&A) decisions, particularly where corporate control may be relatively weak. One managerial objective may be empire-building. Executive compensation tends to increase with firm size, so managers may hope to achieve personal financial gains by engaging in M\&As, although at least in part, the higher observed compensation of the managers of larger institutions rewards greater skill and effort. To protect their firm-specific human capital, some managers may also attempt to reduce insolvency risk below the level that is in shareholders' interest, perhaps by diversifying risk through M\&A activity.

There is evidence that banking organizations may overpay for acquisitions when corporate governance structures are not sufficiently well-designed to align managerial incentives with those of owners. For example, banks that have addressed managerial agency problems through high levels of managerial shareholdings and/or concentrated ownership experience higher (or less negative) abnormal returns when they become acquirers than banks that have not addressed these agency conflicts as well. In addition, abnormal returns at bidder banks are increasing in the sensitivity of the CEO's pay to the performance of the firm and to the share of outsiders on the board of directors (Allen and Rai, 1996; Cornett and Tehranian, 1992). This evidence suggests that entrenched managers with little pay sensitivity to performance or outside directors may make acquisitions that do not maximize shareholder wealth.

Managerial entrenchment may also prevent some value maximizing M\&As. This is possible by reducing the willingness of some financial institutions to become targets of M\&As. One study found that banks in which managers hold a greater share of the stock are less likely to be acquired and that this effect is much larger at banks where management leaves following an acquisition (Houston, James and Ryngaert, 2001). This is consistent with the idea that management teams with large ownership stakes can be a hindrance and can, in fact block outside acquisition.

In modelling overconfidence in the simplest possible way, Milbourn et al (1999) assume that there is a fraction of CEOs in the overall sample of CEOs who are overconfident in the sense that they overestimate the probability of success while managing a larger bank. That is, the probability of success enjoyed by a talented CEO managing a large size bank is assessed to be higher by an overconfident CEO than by a rational CEO. They also assume that overconfident CEOs know 
that the rest of the market assesses a lower success probability in managing a large size bank.. They also observe that overconfident and rational CEOs are equally valuable to the firm in terms of their ability to produce successful outcomes and that CEO wages are reputation-dependent.

In their study Milbourn, et. al. (1999) concludes that the larger asset base leads to a lower probability of success and the idea is that it is generally more difficult to manage a larger bank. This is a natural assumption. There is no doubt that managing a larger firm requires confronting more serious agency problems that call for greater coordination skills. Greater size also forces the CEO to make difficult decisions regarding resource allocation that are linked to a single corporate vision and a strategy that is integrated across the various units of the larger firm.

Acquisitive growth has become a highly popular strategy in recent years. Thus, more attention has been focused on its outcomes. Specifically, the extent acquisitions serve as a substitute for innovation, energy and attention required during negotiations, increased use of leverage, increased size, and greater diversification may affect managers' risk orientations. Because of these effects, managers may reduce their commitment to innovation. The implications of the relationships specified in the model are also examined (Hitt, Hoskisson and Ireland, 1990).

Another direct effect is the amount of managerial energy absorbed by the acquisition process. Such absorption results in a lower propensity for other managers within the firm to pursue risky projects that require the support of top-level managers whose energies are directed primarily toward the acquisition process. A third direct effect is the increased debt levels that often are necessary to finance acquisitive growth (Michel and Shaked, 1985). As debt-holders gain power relative to other stakeholders, the acceptability of pursuing risky projects may decrease. This outcome may occur because debt holders are usually more risk averse than equity or stockholders (Smith and Warner, 1979; Williamson, 1988).

There are also certain attributes of a firm that tend to change when a merger or an acquisition is completed. These attributes, which affect managerial commitment to innovation, are related to the way the newly combined firm is managed. Included among these attributes are firm size level of diversification, and the organizational control systems that they produce. Almost by definition, firms pursuing growth through acquisitions become larger and the range of their operations may become more diversified. In turn, increasing size and diversification affect the types of control systems that are used within the acquiring firm following an acquisition. For instance if, through acquisitions, a firm continues to diversify beyond its center of gravity or beyond the ability of its managers to control the firm's operations, the indirect result may be loss of strategic control (Galbraith and Kazanjian, 1986; Hill and Hoskisson, 1987).

That is, managers may find that they are attempting to compete in a business that they do not understand fully. Furthermore, managers may find their ability to manage is bounded by the information-processing requirements in the firm's new competitive markets. In such instances, managers may substitute financial evaluation criteria for strategic criteria. These substitutions occur because managers may not have the expertise required to process richer strategic information (financial criteria require less information processing). Acquisitive growth may also increase firm size to a level that necessitates reliance on more formalized, bureaucratic controls (Hitt, Hoskisson and Ireland, 1990).

In the popular business literature it is argued that often, after acquisitions, resources allocated to an acquired firm's research and development projects are reduced or, in some cases, eliminated (Siwolop, 1987). Proponents of this view suggest that these actions are taken partially because of trade-offs that occur. For example, acquisitions may serve as a substitute for innovation. Additionally, investment in R\&D may be reduced in order to increase short-term profits to pay for debts and related costs incurred in completing an acquisition (Clark and Malabre, 1988).

Perceived risk affects the relationship between acquisitive growth and commitment to innovation. Internal development may be perceived by managers to entail high risk because of the low probability of innovation success and the length of time required for innovation to provide adequate returns (Clark and Malabre, 1988; Biggadike, 1979). It has been found, that for example, that new ventures require an average of 8 years to achieve profitability and 12 years to generate adequate cash flows leading to the conclusion that new internal ventures were very risky (Biggadike, 1979),

Mansfield (1969) and Hill and Snell (1989) agree with the high risk of internal development because of the large failure rate of innovations. Mansfield (1969) estimated that up to 88 percent of innovations fail to achieve adequate returns on investment. Consistent with this position, Hill and Snell argue that although innovation was in the best interests of, and preferred by, stockholders, managers bear the consequences of its failure. Thus, top-level managers prefer to invest fewer resources in internal development (e.g. R\&D) when faced with resource constraints or when other attractive investment alternatives exist.

Acquisitions may serve as an attractive alternative to investment in R\&D because they offer immediate entrance to a new market and/or a larger share of a market served currently by the firm (Balakrishnan, 1988; Shelton, 1988). While risk does exist, the outcomes are more certain and can be estimated (or forecasted) more accurately with acquisitions than with internal development. Collier (1983) argues that acquisitions have become a common means of avoiding risky R\&D expenditures.

Burgelman (1986) suggests that firm growth and development can be achieved through either acquisitions or innovations. However, because of resource constraints, most firms emphasize one or the other approach. For example, acquisitions often require significant resource commitments resulting in fewer resources to invest in other strategies. Acquisitions may therefore, serve as a substitute for innovations, particularly when resources are inadequate to pursue both acquisitive growth and internal development strategies. Interestingly, once managers begin to purchase innovations by acquisition, their commitment to this approach tends to escalate over time because internal R\&D competency is likely to be reduced. Again, this is especially true when resources are scarce (Hitt, Hoskisson and Ireland, 1990). 
Often the need for substantial resources to complete acquisitions requires that firms resort to the use of debt. As noted previously, firms may trade off payment of debt and debt costs for investments in R\&D. This argument is supported in the empirical literature. Collier (1983), for example, concluded that diversification by acquisition diverts investments from internal development. Michel and Shaked (1985) found that firms acquiring an unrelated business employed more leverage than other types of firms. These firms increase diversification to reduce their business risk, but greater amounts of leverage increase financial risk. Thus, these firms often reduce costs to decrease their financial risk, thereby using the increased returns to pay debt costs and reduce overall debt.

Mintzberg (1979) concludes that lack of capital and an avoidance of risk constitute major barriers to innovation. A lack of internal capital or access to increased equity capital forces firms to employ additional leverage. Williamson (1988) proposes that debt operates largely through a set of strict rules. He suggests that these rules impose higher costs for risky projects where the assets involved are not redeployable for other purposes. The creation of innovation through R\&D involves assets that are largely non-redeployable, suggesting that such activity is unlikely to be financed with debt. Thus, there may be a preference to use debt to fund acquisitions rather than to support R\&D activities. This tendency exists because of a perception of less risk with acquisitions and a belief that such resources are invested in assets that are, for the most part, redeployable. Thus, increased leverage is likely to lead to greater risk aversion. This conclusion is supported by Baysinger and Hoskisson (1989), who found a negative relationship between levels of long-term debt and $R \& D$ expenditures after adjusting for firm size. It appears, then, that increasing levels of debt may produce managerial risk aversion, and in turn, a reduced managerial commitment to innovation.

Frequently, operations in target firms that are being pursued vigorously for acquisition operate in a state of virtual 'suspended animation'. Daily operations continue in the target firm but decisions requiring long-term commitments are often postponed pending outcome of the merger. In fact, managers in the target firm generally are reluctant to make longterm commitments of resources (e.g. R\&D expenditures) unless they do so for defensive purposes (e.g. to reduce the firm's cash position, having the effect of making the firm less attractive as an acquisition candidate). Walsh (1989) and Hirsch (1986) argue that target firm managers involved in such deals often experience job loss and reputation 'wounds'. It is the process of acquisitions that creates a short-term perspective and heightened risk aversion among the top-level managers of both the acquiring and target firms.

Once the merger is completed, the process of post-merger integration becomes critical (Shrivastava, 1986; Sales and Mirvis, 1998; lamount and Anderson, 1985). It has been estimated that almost one-half to two-thirds of all mergers simply do not work and that one-third of all merger failures are caused by faulty integrations (Sales and Mirvis, 1998). Ravenscraft and Scherer (1987) conservatively estimate that one-third of all acquisitions completed in the 1960s and 1970 s have been divested. These facts suggest that, managers must devote time and energy to assimilate successfully an acquired firm hence once the acquisition has been completed successfully, and the merged firm's integrated, effective management of the newly formed firm becomes critical. As a result, the effects of increased size and diversification become important issues for top-level managers.

\section{METHODOLOGY}

We adopted the descriptive survey method of research in this paper. For analyses, primary data were obtained through the survey method using oral interview and questionnaire. The population of this study comprised all consolidated banks in Nigeria. We conducted a pilot survey where 20 copies of the questionnaire were distributed twice to a random sample of individuals in listed banks, specifically to management and non-management staff of these Commercial Banks. The pilot survey was designed to assist in determining the sample size to be used in this study and test the reliability of the research instrument. To generate the $p$ and $q$ for the sample size formula, the participants in this pilot study were requested to give their general impression of the post-consolidation era. Fifty percent of the respondents returned positive rating, while $50 \%$ gave negative rating. There were no undecided cases.

Since it is was impossible to reach the entire population, we used the Freud and Williams formula as cited in Nwabuokei (2001) to determine the sample size of both management and non management staff (managers and non-managers) of these commercial banks.

The Freund and Williams formula as cited in Nwabuokei (2001) is given as:

$$
n=\frac{Z^{2} p q}{e^{2}}
$$

where:

$\begin{array}{lll}\mathrm{n} & = & \text { sample size } \\ \mathrm{p} & = & \text { percentage of positive response } \\ \mathrm{q} & = & \text { percentage of negative response } \\ \mathrm{e} & = & \text { margin of error } \\ \mathrm{Z} & = & \text { level of confidence }\end{array}$

From the result of the pilot study, the $p(0.5)$ and the $q(0.5)$ were generated. At $\propto=0.05$ (margin of error), $Z=1.96$. Thus, we have: 


$$
n=\frac{(1.96)^{2}(0.5)(0.5)}{(0.05)^{2}}=\frac{3.8416(0.25)}{0.0025}=\frac{0.9604}{0.0025}=384.16
$$

Thus, the total sample size for this study was 384 respondents comprising 144 managerial staff and 240 non managerial staff of commercial banks in South East Nigeria.

For the purpose of this study, we used the questionnaire as the major instrument for collection of primary data. We designed the questionnaire with structured questions. The questions structured using mainly 5-point Likert scale provided respondents with possible answers and asked that the respondents select those that apply. It should be noted that the structured questions were easier for the respondents to answer; and were more reliable because of the fixed presentation of questions and responses. The questionnaire gathered was used to analyze the data for ease of comprehension. Interview to key persons in the field was also conducted to have their impressions on the core issues in this paper. The responses were used to complement data generated from the questionnaire. For presentation and data analysis, tables and percentages were used to summarize the data gathered for clarity and comprehension while the Normal Distribution and Chi-square $\left(X^{2}\right)$ statistic were used to test the hypotheses

\section{PRESENTATION AND ANALYSIS OF DATA}

From the three hundred and eighty-four (384) copies of questionnaire distributed to managers and non-managers of commercial banks in South East Nigeria, a total of three hundred and twenty five (325) copies of the questionnaire were correctly filled and returned. Table 4.1 presents the response rate of questionnaire distributed.

TABLE $4.1 \quad$ Response Rates of Respondents

\begin{tabular}{|l|l|l|l|}
\hline Staff & $\begin{array}{l}\text { Copies of } \\
\text { Questionnaire } \\
\text { Distributed }\end{array}$ & $\begin{array}{l}\text { Copies of Questionnaire } \\
\text { Returned }\end{array}$ & $\begin{array}{l}\text { Percentage } \\
\text { Response (\%) }\end{array}$ \\
\hline Managerial Staff & 144 & 139 & 42 \\
\hline Non Managerial Staff & 240 & 186 & 58 \\
\hline Total & 384 & 325 & 100 \\
\hline
\end{tabular}

\section{Source: Field Survey, 2013}

The table 4.2 presents the responses from managerial and non-managerial staff based on managerial commitment of managers of commercial banks in Nigeria due to mergers and acquisition.

Table 4.2 Response on Managerial Commitment of Managers

\begin{tabular}{|l|l|l|l|l|}
\hline Stakeholder & Managers & Non-Managers & Total & $\%$ \\
\hline Strongly agree & 45 & 61 & 106 & 33 \\
\hline Agree & 68 & 56 & 124 & 38 \\
\hline Undecided & 3 & 9 & 12 & 4 \\
\hline Disagree & 12 & 19 & 31 & 10 \\
\hline Strongly disagree & 11 & 41 & 52 & 15 \\
\hline Total & 139 & 186 & 325 & 100 \\
\hline
\end{tabular}

\section{Source: Field Survey, 2013}

Table 4.2 thus, depicts the consolidated responses for objective one of this study. It reveals that one hundred and six (106) respondents representing $33 \%$ of stakeholders strongly agreed mergers and acquisitions had significant positive effects on managerial commitment of managers of commercial banks in the South East region of Nigeria. A breakdown indicates that forty-five (45) of the respondents were managers of commercial banks and sixty-one (61) respondents were non-managers of commercial banks. One hundred and twenty-four (124) respondents representing $38 \%$ of stakeholders agreed mergers and acquisitions had significant positive effects on managerial commitment of managers of commercial banks in the South East region of Nigeria. A breakdown of this indicates that sixty-eight (68) of the respondents were managers of commercial banks and fifty-six (56) respondents were non-managers of commercial banks. Twelve (12) respondents, representing $4 \%$ of stakeholders, were undecided that mergers and acquisitions had significant positive 
effects on managerial commitment of managers of commercial banks in the South East region of Nigeria. A breakdown indicates that three (3) respondents were manager of a commercial bank and nine (9) respondents were non-managers of commercial banks.

Thirty-one (31) respondents, representing 10\% of stakeholders, disagreed that mergers and acquisitions had significant positive effects on managerial commitment of managers of commercial banks in the South East region of Nigeria. A breakdown of this indicates that twelve (12) of the respondents were managers of commercial banks and nineteen (19) respondents were non-managers of commercial banks. Lastly, fifty-two (52) respondents representing $15 \%$ of stakeholders strongly disagreed that mergers and acquisitions had significant positive effects on managerial commitment of managers of commercial banks in the South East region of Nigeria. A breakdown indicates that eleven (11) of the respondents were managers of commercial banks and forty-one (41) respondents were non-managers of commercial banks.

From the personal interview carried out, respondents strongly agree that mergers and acquisitions had significant positive effects on managerial commitment of managers of commercial banks in the South East region of Nigeria. Stakeholders generally agreed that the positive significant effect was due to changes in managerial personnel of commercial banks. This induced a renewed sense of commitment to roles and realignment to the achievement of the vision of these banks in providing the necessary environment that will facilitate the intermediation function of Nigerian's commercial banks in line with the objectives of the Central Bank of Nigeria consolidation policy.

\section{Test of Hypothesis}

The hypothesis stated was tested using three steps. Step one involved the restatement of the hypotheses in null and alternate forms. Step two incorporates presentation of table for analysis and analysis of SPSS results while step three involved decision.

\section{Step One: Restatement of Hypothesis in Null and Alternate forms}

$\mathbf{H}_{\mathbf{0}}$ : Mergers and acquisitions have no significant positive effect on managerial commitment of Nigerian commercial banks in South East Region of Nigeria

$\mathbf{H}_{\mathrm{a}}$ : $\quad$ Mergers and acquisitions have significant positive effect on managerial commitment in Nigerian commercial banks in South East Region of Nigeria

\section{Step Two: Presentation of Table and Analysis of SPSS Results}

Recall that table 4.2 contains the responses from managers and non-managers. Information from the table are used to test our hypothesis stated in stage one. The results of the test are presented in table 4.3.

Table 4.3: SPSS Chi-Square Tests Result for Hypothesis One

\begin{tabular}{|c|c|c|c|}
\hline & Value & $\mathrm{df}$ & Asymp. Sig. (2-sided) \\
\hline Pearson Chi-Square & $70.981(\mathrm{a})$ & 12 & .000 \\
Likelihood Ratio & 66.428 & 12 & .000 \\
$\begin{array}{c}\text { Linear-by-Linear } \\
\text { Association } \\
\text { N of Valid Cases }\end{array}$ & 28.336 & 1 & \\
\hline
\end{tabular}

\section{Source: SPSS Results}

From table 4.3, stakeholders' (managers and non managers in Nigeria's South East region) perception from the results show that the mergers and acquisitions had significant positive effect on managerial commitment of managers of Nigerian commercial banks $\left(X_{c}^{2}=70.98>X_{t}^{2}=21.0\right.$ at 12 degrees of freedom and 0.05 level of significance).

\section{Step Three: Decision}

The null hypothesis is rejected while the alternate hypothesis is accepted. Thus, bank mergers and acquisitions had significant positive effect on managerial commitment of managers of commercial banks in Nigeria's South East Region within the period studied.

\section{CONCLUSION AND RECOMMENDATION}

Managers may be able to pursue their own objectives in consolidation decisions, particularly in banking where corporate control may be relatively weak. One managerial objective may be empire-building. Executive compensation tends to increase with firm size, so managers may hope to achieve personal financial gains by engaging in M\&As, although, at least in part, the higher observed compensation of the managers of larger institutions rewards greater skill and effort. To protect their firm-specific human capital, some managers attempt to reduce insolvency risk that is in shareholders' interest, perhaps by diversifying risk through M\&A activity. There is evidence that banking organizations may overpay for 
acquisitions when corporate governance structures are not sufficiently well-designed to align managerial incentives with those of owners. For example, banks that have addressed managerial agency problems through high levels of managerial shareholdings and/or concentrated ownership experience higher (or less negative) abnormal returns when they become acquirers than banks that have not addressed these agency conflicts as well. This suggests that managers are more sensitivity to performance during periods of consolidation. This implies that managerial role and commitment are significantly and positive enhanced after M\&A. The results of this study that bank consolidation have significant and positive effect on managerial role and commitment of commercial banks managers in Nigeria's South East region are in line with research findings of Allen and Gale (2000) and Cornett and Tehranian (1992).

One of the advantages of the banking sector consolidation that is often harped on is its potential for firms in the industry to enjoy economies of scale. Another issue related to the small size of Nigerian banks is the high cost of intermediation epitomized by the wide spread between deposit and lending rates. It would be recalled that the desire of the government to have a single digit lending rate has remained a mirage due, mainly, to the high cost of intermediation. Globally, size has become an ingredient for success. An enhanced capital-base, all things being equal, is expected to confer competitive edge on a bank and this obviously will require a high sense of commitment from managers of these deposit money banks especially given the volatile nature of the region. This study therefore, recommends that incentive measures such as high pay, good working environment should be provided during M\&As in respect of commercial banks as they will further enhance managerial commitments.

\section{REFERENCES}

[1] Allen, F and D. Gale (2000) European Public Takeover Bids, London: Allen \& Overy

[2] Allen, L. and Rai A. (1996), "Operational efficiency in banking: An international comparison," Journal of Banking and Finance, 20, May

[3] Balakrishnan, S. (1988), "The prognostics of diversifying acquisitions", Strategic Management Journal, 9

[4] Baysinger, B. D. and R. E. Hoskisson (1989), "Diversification strategy and R\&D intensity in large multiproduct firms", Academic of Management Journal, 32

[5] Berger, A.N. and D.B. Humphrey (1997), "Efficiency of financial institutions: International survey and directions for future research" European Journal of Operational Research, 98

[6] Berger, A.N. and L.J. Mester (1997), "Inside the black box: What explains differences in the efficiencies of financial institutions?", Journal of Banking and Finance, 21:895-947

[7] Berger, Allen N., R. S. Demsetz, and P.E. Strahan (1999), "The Consolidation of the Financial Services Industry: Causes, Consequences, and Implications for the Future". Journal of Banking \& Finance 23

[8] Berger AN, Saunders A, Scalise JM, G.F. Udell (1998), "The Effects of Bank Mergers and Acquisitions on Small Business Lending," Journal Finance and Economics 50

[9] Biggadike, R (1979), "The risky business of diversification”, Harvard Business Review, 57

[10] Burgelman, R. (1983), "Managing corporate entrepreneurship: New structures for implementing technological innovation" In M. Horwitch (ed.), Technology in the Modern Corporation, New York: Pergamon Press

[11] Clark, L. H., Jr and A. L. Malabre, Jr (1988), Slow rise in outlays for research imperils U.S. competitive edge', Wall Street Journal, 16: A1 and A5

[12] Collier, D. W. (1983), "Technology in diversified, decentralized companies”, Journal of Business Strategy, 3

[13] Cornett, M.M. and H. Tehranian (1992), "Changes in Corporate Performance Associated with Bank Acquisitions", Journal of Financial Economics 31

[14] DeYoung, R. (1997), "Bank mergers, X-efficiency, and the market for corporate control”,a Managerial Finance, 23

[15] Galbraith, J. R. and R. K. Kazanjian (1986), Strategy Implementation: Structure, Systems, and Process, St Paul, MN:West Publishing

[16] Haynes, M. and S. Thompson (1999), "The productivity effects of bank mergers: Evidence from the UK building Societies", Journal of Banking and Finance, 23

[17] Hill, C. W. L. and R. E. Hoskisson (1987), "Strategy and structure in the multiproduct firm", Academy of Management Review, 12

[18] Hill, C. W. L. and S. A. Snell (1989), "Effects of Ownership Structure and Control on Corporate Productivity", Academy of Management Review, 32

[19] Hirsch, P. M (1986), "From ambushes to golden parachutes: Corporate takeovers as an instance of cultural framing and institutional integration", American Journal of Sociology, 91

[20] Hitt, M.A Hoskisson, R.E and Ireland, R.D (1990), "Mergers and Acquisitions and Managerial Commitment to Innovation in M-Form Firms," Strategic Management Journal, Vol. 11, Special Issue, Summer 
[21] Houston, J.F., James, C.M. and M.D Ryngaert (2001), "Where Do Merger Gains Come from? Bank Mergers from the Perspective of Insiders and Outsiders", Journal of Financial Economics 60

[22] Lamont, B. T. and C. R. Anderson (1985), "Mode of Corporate Diversification and Economic Performance", Academy of Management Journal, 28

[23] Lemo, T. (2005), "Regulatory Oversight and Stakeholder Protection" A Paper Presented at the BGL Mergers and Acquisitions Interactive Seminar, held at Eko Hotels \& Suits. V. I., on June 24

[24] Mansfield, E. (1969), Industrial Research and Technological Innovation, New York: Norton

[25] Michel, A. and I. Shaked (1985), "Evaluating merger performance”, California Management Review, 27

[26] Milbourn T.T., Boot A.W.A., and Thakor A. V. (1999) Journal of Banking and Finance, 23

[27] Mintzberg, H. (1979), The Structuring of Organizations. New York: Prentice-Hall

[28] Molyneux, P., Altunbas, Y and E. Gardener (1996), Efficiency in European banking, Chichester: Wiley

[29] Nwabuokei, P.O. (2001), Fundamental of Statistics, Enugu, Chuka Printing Company Ltd

[30] Peristiani, S. (1997), "Do Mergers Improve the X-Efficiency and Scale Efficiency of U.S. Banks? Evidence from the 1980s," Journal of Money, Credit, and Banking 29

[31] Ravenscraft, D. J., and F. M. Scherer (1987), "Mergers, Sell-offs, and Economic Efficiency", Washington, D.C.: Brookings Institution

[32] Rhoades, S.A. (1998), "The efficiency effects of bank mergers: An overview of case studies of nine mergers", Journal of Banking and Finance, 22

[33] Sales, A. L. and P. H. Mirvis (1998), "When cultures collide: Issues in acquisition" In J. R. Kimberly and R. E. Quinn (eds), Managing Organizational Transitions, New York; Prentice Hall

[34] Shelton, L. M. (1988), "Strategic Business Fits and Corporate Acquisition: Empirical Evidence", Strategic Management Journal, 9

[35] Shrivastava, P. (1986), "Postmerger integration", Journal of Business Strategy, 7

[36] Siwolop, S. (1987), "Research spending is building up to a letdown", Business Week, 22

[37] Smith, C. L. and J. B. Warner (1979), "Bankruptcy, Secured Debt, and Optimal Capital Structure: A Comment", Journal of Finance, 34

[38] Vander V. R. (2001), "Cost and profit efficiency of financial conglomerates and universal banks in Europe", Journal of Money, Credit and Banking, Vol 14

[39] Walsh, J. P. (1989), "Doing a deal: Merger and acquisition negotiations and their impact upon target company top management turnover", Strategic Management Journal, 10

[40] Williamson, O.E. (1988), "Corporate Finance and Corporate Governance", Journal of Finance, Vol 48 